\title{
Competitive advantages of firms in agro-industrial clusters: Study of wine in Brazil and Chile
}

\author{
Adilene Alvares Mattia ${ }^{1, a}$, Janaina Macke $^{1}$, Janete Sttofel $^{2}$, and Daniel Miranda Sala ${ }^{3}$ \\ ${ }^{1}$ Universidade de Caxias do Sul, Carvi - Centro de Ciencias Sociais e Educacao, Av. Alameda Joal Dal Sasso, 800, Bento \\ Goncalves - RS, and Brazil \\ ${ }^{2}$ IFFS - Departamento de Economia, BR 158, Km 405 Laranjeiras do Sul - PR, Brazil \\ ${ }^{3}$ Universidad de Valparaiso - Departamento de Ing. Civil Industrial, Errazuriz, Valparaiso 1834, Chile
}

\begin{abstract}
This study aims to explore two cases connected to the wine productive chain, emphasizing the process of competitive advantages creation under the logic of industrial clusters. The analyzed experiences deal with agglomerations of companies, where some are already established, while others are consolidated or under expansion: The Vale dos Vinhedos (Brazil), and Valle de Casablanca (Chile). The comparative study was based on the presence of territorial resources, analyzed in categories, of which we can highlight: denomination of origin (D.O.), tourism, economy, political situation and unique value. The analysis of both territories allowed the identification of similarities and potentialities, and the attachment of those with the construction of competitive advantages. The results show that the competitiveness of companies established on the Vale dos Vinhedos and Valle de Casablanca is determined by the competitiveness of the territory, meaning that the spaces under analysis perform a fundamental role in the process of creation of competitive advantages of the already installed companies.
\end{abstract}

\section{Introduction}

When facing the capacity that certain territories show with respect to the formation of networks, clusters can be observed, which can be defined as a geographical concentration of companies and institutions interconnected in a determined field of activity. The clusters cover a variety of companies, institutions and entities connected between themselves. They include, for example, specialized input suppliers such as components, machinery, services and specialized infrastructure [1].

The importance of clusters is in its role of forming and sustaining competitive advantages, or, in other word, the local resources (territorial) influence the value of the internal resources of companies inserted in such context. In that way, the source of competitive advantages are linked to the strategic resources that the companies have or can access, in the articulation between the place, its agents and its processes.

In the context of contemporaneous globalization, each place is, at the same time, object of a global reason and a local reason, living dialectically [2]. In that sense, this study aims to understand the development of clusters, starting from their socio-spatial formations and interpreting them from the use of their territories. Under that context, the clusters represent a new form of regional organization, between short-distance markets on one side, and of hierarchies or vertical integration on the other. A cluster is, therefore, an alternative way of value chain organization. The creation of value in the productive chain

${ }^{a}$ Corresponding author: aamattia@ucs.br from strategic resources is based on the Resource Based View (RBV) theory, which says that companies differ significantly based on their capacity to accumulate resources, and based on the way they use these resources across time $[3,4]$. These resources, accumulated and developed internally, can result in organizational competence through the collective learning and the way these individuals coordinate and manage the business areas of the company.

The central question that orients and directs the research is to verify how the territory influences the access and internalization of the resources generated externally to the cluster [5], and how companies inserted into this cluster combine these external resources with those generated internally in the process of creating and sustaining competitive advantages. The focus is on the potential of agroindustrial companies inserted in two winery regions: the Vale dos Vinhedos (Brazil), and the Valle de Casablanca (Chile). As the academic contribution of the study, we propose the complementary use of the concept of cluster (originated in the porterian strand) with the concept of resource, in this case, territorial (originated in the RBV strand).

It's worth mentioning that this study is composed of a preliminary and exploratory analysis based on the research project denominated Territory, strategic resources, value creation and competitive advantages. In structural terms, besides this introduction, a theoretical approach is presented, while the second section of the text talks about territory, business strategy and competitiveness. The third section details the two regions under study, presenting also the characteristics of the winery agro-industrial system. On the fourth section the final considerations are made, and lastly the references used in this paper are listed. 


\section{Territory, territorialization and competitiveness}

In this study, we consider the notion of territory under change, taking its content or its "form-content": the analyzed territory are something under process. In that way, it is the territory that "constitutes a trace of union between the past and the immediate future" [2, p. 19]. Territory is a fraction of space where inter-relations between the social actors and institutions there present are build [6].

The territory is always and contemporaneously appropriation (on a symbolic sense) and dominance (on a more concrete, political-economic sense) of a space that is socially shared and not simply built [7]. A territory is defined by social formation aspects, such as socio-economic and political-ideological aspects [8-10].

The territorial development, according to [6], refers to a localized process of development in a determined territory, that involves the social, human, economical, physicalnatural, environmental, political and cultural dimensions, and that can be observed in a small location or an aggregation of such small location.

It is in the territorial context that the debates about the role of industrial districts and local productive arrangements are inserted, as well as the clusters (these being considered as environments promoters of competition, innovation and economic development).

In this study we highlight the use of the territory as a revealing category of analysis of the social dynamics that these groups, industrial districts, local productive arrangements and clusters imprint on the demarcated spaces. By being anchored in its spatial practices, for example, what Correa [11] called spatial selectivity - the choice of a place that presents attributes of interest with the established projects.

On the other side, we could also consider it as a spatial re-embodiment, because it derives from a political view of the institution, aiming to impose another rationality to its space of actuation that, through the integration of these companies and the creation of locational nuclei (clusters), originated another spatial organization.

The industrial district approach begins with the accelerated growth phenomena that originated in Italian territory, also known by the expression Third Italy. The existence of a homogeneous system of values, expressing a work ethic, of family and dynamism consists in one of the first characteristics of the district. On the description of an industrial district Becattini [12, p. 20] identifies it as "a socio-territorial entity characterized by the active presence of a community of people and of a population of companies in a determined geographical and historical space". According to the author the system of values, propagated through institutions (market, company, family, church, school, authorities, political and syndical organizations, public, private, economic, political and cultural instances, of social, religious and artistic solidarity) that involves the society with the industrial district contributes to the entrepreneurial spirit and the introduction of innovations.

The value system pointed by Becattini [12] is defined by other authors as social capital. The social capital is understood as a characteristic of social organizations, and has as its main elements the trust, the norms and the networks, therefore, the reciprocity reduces the costs of transaction, eases the collective actions and, through the social interactions, contributes to the diffusion of knowledge and innovation.

In a complementary way, Radomsky and Schneider [13] point to the reciprocity relationships as important to the maintenance and strengthening of the networks that form on the territory and are realized by diverse agents. To the authors "the changes imposed through the networks are constant in the social and economic dynamics, because this net of relationships is constantly doing itself, and the texture of the networks is always in the eminence of the transformations and the reinvention of the territorialities" ([13], p. 277).

Studies about clusters emphasize that the geographical proximity allows the development of cooperative relationships based on trust, which starts to exist and intensifies itself between the different actors and agents. These relationships are essential in the exploration of competitive advantages that are created and diffused inside certain territories.

For a company to obtain a sustainable competitive advantage, it must have strategic resources and be capable of creating value to the market based on these resources. However, the strategic value of the resources will depend on the combination that the company will make of said resources, and the trajectory that the organization will follow [14], creating a value creation strategy that cannot be easily implement by the current and potential competitors.

\section{The studied regions: Vale dos Vinhedos in Brazil, and Valle Casablanca in Chile}

In this section the characteristics of the grape and wine producing regions are presented, on the State of Rio Grande do Sul, on Vale dos Vinhedos (RS/Brazil), and on Valle Casablanca (Valparaiso, Chile). The regions are considered wine clusters, internationally known.

\subsection{Vale dos Vinhedos (RS/Brazil)}

Located in the South Region of Brazil, more specifically in the Serra Gaucha, the Vale dos Vinhos has a total area of $81 \mathrm{~km}^{2}$, median altitude of $740 \mathrm{~m}$ and covers part of three cities: Bento Goncalves (northeast), Monte Belo do Sul (northwest) and Garibaldi (south). According to Matheus and Silva ([15], p. 62), "the region is marked by slopes covered with vineyards and small agricultural communities, that surround the road RS 444, being there localized one of the biggest and most reputable national companies that produce drinks derived from grapes". With median temperature around $17^{\circ} \mathrm{C}$ and pluviosity in the $1800 \mathrm{~mm} /$ year range, the Vale dos Vinhedos is classified as a humid temperate climate. With approximately 2100 hectares of vines, the Vale dos Vinhedos produces annually around 20 million liters of fine wines, considered one of the main fine wine producing regions in Brazil [16]. The Vale represents the historical, cultural and gastronomical legacy left by the Italian immigrants that arrived in the region in 1875. According to Zanini and Rocha [17], these immigrants introduced the viticulture and even nowadays this 
constitutes the base of the local family incomes. In Vale dos Vinhedos there are approximately 3000 inhabitants that in most part work on the cultivation of vines. The output of this production equals to wines produced in family properties or commercialized in winery cooperatives of the region. The productive structure of the Vale is composed by small rural properties that share the territory with wineries of different sizes. These wineries are composed of family wineries, boutiques and garage, as well as big companies that count on international partnerships [18]. This region consists of a sub-region of Serra Gaucha, and obtained the first Geographical Indication of Brazil: the Indication of Origin Vale dos Vinhedos [19]. With the D.O. (denomination of origin) the Vale dos Vinhedos has intensified the work with types like Merlot and Chardonnay, typical of the region. Owned of the first D.O. recognized by the OIV (Office International de la Vigne et du Vin) in Latin America, the Vale dos Vinhedos is an important tourist destination in Brazil, being the biggest sector the eno-gastronomy, receiving in the year of 2013 more than 283 thousand visitors with an annual production of 9 million of liters of wines and sparklings [16]. The geographical characterization denominated Vale dos Vinhedos, Fig. 1 , has made possible the acquisition of the D.O. for fine wines produced in the district with that denomination, summed by parts of the Garibaldi and Monte Belo do Sul cities [18].

\subsection{The Valle Casablanca (Valparaiso/Chile)}

In between the Andes and the Coast Mountain Chain, at the Costeira do Aconcagua plain, is located the Valle de Casablanca (province of Valparaiso). The valley location, Fig. 2, is on the V Chilean Region, between the Coast Mountain Chain and the Pacific Ocean. It's on route 68, that unites Santiago, Chile's capital, with Valparaiso, main Chilean port. In terms of distance, it is $80 \mathrm{~km}$ to the northwest of Santiago and $41 \mathrm{~km}$ of Valparaiso and Vina del Mar [21].

With a terrestrial surface of approximately $220 \mathrm{~km}^{2}$, the Valle de Casablanca stands out are the third biggest

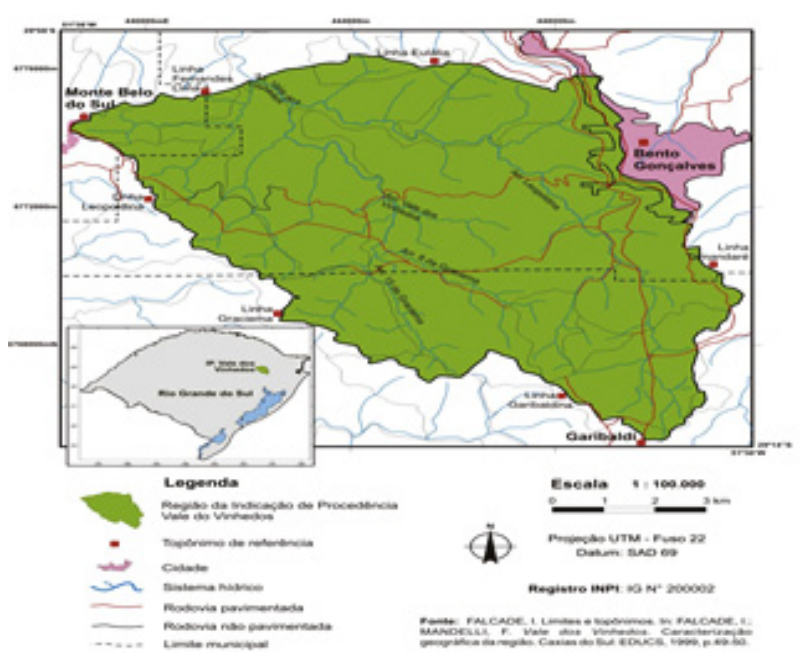

Figure 1. D.O. Region from Vale dos Vinhedos [20].

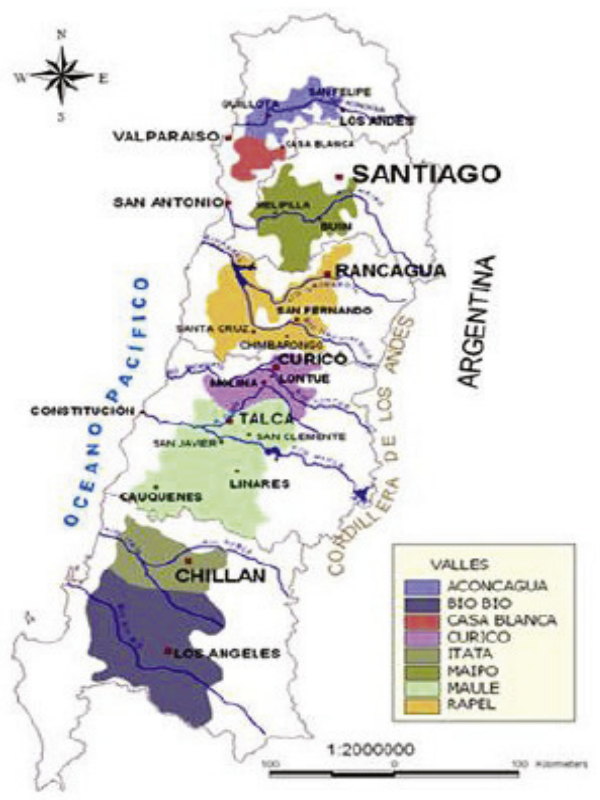

Figure 2. Map of Valle de Casablanca Region [22].

wine producing region of Chile, with a planted area of more than 6 thousand hectares and annual production volume in the 34 million liters range. With an altitude that doesn't goes above $200 \mathrm{~m}$ and pluviosity in the 450 annual $\mathrm{mm}$, the Valle de Casablanca has a cold climate with average temperature around $14.4^{\circ} \mathrm{C}$. The regional climate suffer maritime influence due to the close distance from the sea, being common the morning fogs and great thermal amplitude. The proximity with the sea favors the climate to produce white wines, due to the fact that grapes mature more slowly ([22], p. 24).

The viticulture history of Valle Casablanca starts at the end of the 1970's, with the sowing of the first grape hectares. Through a decade the planted area was enlarged to 4000 hectares, where the Valle Casablanca went from a poor rural community with approximately 16 thousand inhabitants, to one of the most attractive poles of the region [22].

The white wines (Chardonnay and Sauvignon Blanc) from Valle de Casablanca are recognized internationally, being classified as one of the ten main wine capitals of the world in June 2013, by GWC (Great Wice Capitals) - a global network that promotes tourism. Between 2007 and 2011 the Chilean wine production grew 29\%, increasing the participation of the country on the global production, in such a way that in 2011 the country became the eight biggest wine producer in the world ([22], p. 18).

On Table 1 the characteristics of both clusters are presented, with respect to the territorial resources.

\section{Final considerations}

Currently it is common to talk about competitiveness of territories through competitiveness of the companies. Are the companies competitive, or are the territories also competitive? [23]. For the regional scientists there is a consensus that territories are an important competitive factor, to the point of having a theoretical solid body that explains 
Table 1. Comparison between both clusters.

\begin{tabular}{|c|c|c|}
\hline & Vale dos Vinhedos & Valle de Casablanca \\
\hline Geographical Indication & $\begin{array}{l}\text { First Brazilian Geographical Indication } \\
\text { (2002). The DO was obtained in } 2012 .\end{array}$ & $\begin{array}{l}\text { Aconcagua Denomination of Origin (2001). First } \\
\text { coast region of cold climate. In 2011, new wine } \\
\text { regions: Andes, between Cordilheiras e Costa. The } \\
\text { Valle de Casablanca was classified in the Chile } \\
\text { Costa region. }\end{array}$ \\
\hline Political Situation & $\begin{array}{l}\text { Region that covers } 3 \text { cities: Bento Gonçalves } \\
(60 \%) \text {, Garibaldi (33\%) and Monte Belo do } \\
\text { Sul (7\%) }\end{array}$ & $\begin{array}{l}\text { The Valparaiso region is composed of seven regions: } \\
\text { San Antonio, Quillota, Petorca, San Felipe, Los } \\
\text { Andes, Isla de Pascua and Valparaíso. }\end{array}$ \\
\hline Area & $81,23 \mathrm{~km}^{2}$ & $386 \mathrm{~km}^{2}$ \\
\hline Population & 3000 inhabitants & 21.874 inhabitants \\
\hline Main Association & $\begin{array}{l}\text { APROVALE (Associação de Produtores } \\
\text { de Vinhos Finos do Vale dos Vinhedos), } \\
\text { founded in } 1995 .\end{array}$ & $\begin{array}{l}\text { Associación Gremial de Empresários Vitivinícolas } \\
\text { del Valle de Casablanca, founded in } 2001 .\end{array}$ \\
\hline Tourism & $\begin{array}{l}\text { Consolidated. Main eno-touristic destination } \\
\text { in Brazil. In the past } 11 \text { years, The number } \\
\text { of tourists that visit the region has grown } \\
\text { from } 45 \text { thousand, in } 2001 \text {, to almost } 250 \\
\text { thousand in } 2012 .\end{array}$ & $\begin{array}{l}\text { Casablanca is part of the ten World Wine Capitals. } \\
\text { The wine valley of the central region, and the } \\
\text { recognized port city, currently are part of the } \\
\text { Great Wine Capitals, global network that aims to } \\
\text { promote the tourism, the culture and the commercial } \\
\text { exchange between the World Wine Capitals. In } 2012 \\
\text { has received } 124 \text { thousand visitors. }\end{array}$ \\
\hline Origins & $\begin{array}{l}\text { In response to the crisis lived by the wine } \\
\text { sector in } 1990 \text { (end of Aurora cooperative), } \\
\text { six small wineries (used to the quantity } \\
\text { paradigm) decided to create an association } \\
\text { (APROVALE) and look for a new direction } \\
\text { for the wine, through the improvement } \\
\text { in quality, the acquisition of technical } \\
\text { knowledge and added value to the product. }\end{array}$ & $\begin{array}{l}\text { It was in the } 80 \text { 's that Casablanca started to produce } \\
\text { the wines that today make it famous, not only at } \\
\text { a national level, and that is why it is considered } \\
\text { a new valley. Currently, the Valle de Casablanca } \\
\text { is positioned as the main developer of Chilean } \\
\text { white vines, amongst which are Sauvignon Blanc, } \\
\text { Chardonnay, Viognier and Marsanne, besides cold- } \\
\text { climate red vines such as Pinot Noir, Syrah and } \\
\text { Merlot. }\end{array}$ \\
\hline Economy & $\begin{array}{l}31 \text { wineries, } 4 \text { of big size (producing more } \\
\text { tan } 500 \text { thousands of liters per year). The } \\
\text { Vale dos Vinhedos is responsible for the } \\
\text { production of } 20 \% \text { of all the fine wine and } \\
25 \% \text { of the sparklings made in Brazil, which } \\
\text { corresponds to between } 12 \text { and } 14 \text { million } \\
\text { bottles per year. There are } 2.132 \text { hectares } \\
\text { of vines that, in } 2011 \text {, produced } 6,9 \text { million } \\
\text { liters of wines and sparklings. } \\
\text { The incoming of dividends with respect to } \\
\text { tourism was, in average, R } \$ 100 \text { million or } \\
\text { US } \$ 31,25 \text { million generated by national and } \\
\text { foreigner visitors. }\end{array}$ & $\begin{array}{l}\text { The association is composed by } 19 \text { agricultural } \\
\text { societies, } 19 \text { wineries and } 6 \text { restaurants. In } 2012 \\
\text { the Chilean tourism industry had a revenue of } \\
\text { US } \$ 2.559,5 \text { million, being US } \$ 2109.9 \text { million } \\
\text { generated by foreign visitors, US\$ } 28,8 \text { million } \\
\text { due to travel agencies and US\$ } 420.8 \text { million } \\
\text { due to international transportation. The planted } \\
\text { surface of its members represents } 94 \% \text { of the total } \\
\text { planted, with } 5.680 \text { hectares, being the total annual } \\
\text { production of wine } 34 \text { million liters }\end{array}$ \\
\hline
\end{tabular}

the competitiveness of the territories, as well as through the production of empirical evidence.

The wine region Vale dos Vinhedos, located in Serra Gaucha, remains the biggest wine producing region in Brazil (responsible for more than $80 \%$ of the national production), and has an ever important and irradiating role in the development of new wine regions, both through the diffusion of technology as well as entrepreneurial actions. On its turn, despite being a younger wine region, in less than 30 years the Valle de Casablanca has established itself as one of the main Chilean producing regions, having being internationally recognized, contributing to the strengthening of the wine sector in Chile, mainly the eno-tourism, that already corresponds to $6 \%$ of the sales in the Chilean market.

In the case of Vale dos Vinhedos, the information obtained so far show that, in the region, some of the competitive advantages are the social capital, observe on the associative organization that is on the surroundings, and also the learning constructed along the time that wine production has been occurring. These factors, added to the social and territorial actors, seem to be factors that contribute to the utilization of resources in favor of development, and usage of the competitive advantages and the awarding of the Vale as a Historical and Cultural Heritage of the Rio Grande do Sul state. 
In Valle Casablanca it is also noted the presence of associative organizations that indicate the importance of the social capital, related to the rapid advance that took place in the constitution of this territory as one of the ten world wine capitals (Great Wine Capitals). In the region the actors learning process related to the wine production can be appointed with bigger highlight than in Vale dos Vinhedos, because in less than fifty years the region has constituted itself in an important wine producing region. The social actors also seem to have a fundamental role in the constitution of the competitive advantages observed.

Another aspect is that, amongst the different agroindustrial clusters, the wine cluster is one of the most complex, both in terms of product attributes as well as the producing and market chains. It is worth mentioning that the results obtained in previous research point to the necessity of a deepening of the analysis and the modelling effort of the internal process of competitive advantages creation, in a cluster environment that follows the general guidelines here proposed.

\section{References}

[1] M.Porter Eugene. Clusters and the New Economics of Competition, Harvard Business Review, p. 77-90, Nov.-Dec. (1998)

[2] M. Santos. Por uma geografia nova. São Paulo: Hucitec (1999)

[3] J.B. Barney. Firm resources and sustained competitive advantage. Journal of Management, 17, n. 1, p. 99-120 (1991)

[4] B. Wernerfelt, A Resource-Based View of The Firm. Strategic Management Journal, 5, pp.171-180 (1984)

[5] J. Fensterseifer Evaldo, J. E. The Emerging Brazilian Wine Industry: Challenges and Prospects for the Serra Gaúcha Wine Cluster, International Journal of Wine Business Research, 19, n. 3, p. 187-206 (2007)

[6] V. Dallabrida Roque, V. Fernández. Desenvolvimento TerritoriaL: possibilidades e desafios, considerando a realidade de âmbitos espaciais periféricos. Passo Fundo: Editora UPF/Ijuí: Editora UNIJUI (2008)

[7] M. Souza. O território: sobre espaço e poder, autonomia e desenvolvimento. In: Castro, Gomes, Correa (Org.) Geografia: conceitos e temas. 8 ed. Rio de Janeiro: Bertrand Brasil (2006)

[8] C. Raffestin. Por uma geografia do poder. São Paulo: Ática (1993)

[9] M. Eduardo. Território, trabalho e poder: por uma geografia relacional. Campo-território: revista de geografia agrária, 1, n. 2, p. 173-195, ago (2006)
[10] M.A.Saquet. Por uma abordagem territorial. In: M. A.Saquet; E.S. Sposito (Org.). Territórios e territorialidades: teorias, processos e conflitos. São Paulo: Expressão Popular (2009)

[11] R. Correa. Região e organização espacial. São Paulo Ática (1986)

[12] G. Becattini. O distrito marshaliano. Uma noção socioeconômica. In G. Benko, A. Lipietz (org). As regiões ganhadoras - distritos e redes: os novos paradigmas da geografia econômica; Oeiras, Celta Editoras, p.19-32 (1994)

[13] G.Radomski; S.Schneider. Nas teias da economia: o papel das redes sociais e da reciprocidade nos processos locais de desenvolvimento. Brasília: Sociedade e Estado, 22, n. 2, p. 249 a 284, maio/ago. (2007)

[14] J. A. Black, K.B Boal. Strategic Resources: Traits, Configurations and Paths to Sustainable Competitive Advantage. Strategic Management Journal, 15 (1994)

[15] L. Matheus Fernando e Silva. De celeiro a cenário: vitivinicultura e turismo na Serra Gaúcha. São Paulo: USP: Faculdade de Filosofia, Letras e Ciências Humanas, Departamento de Geografia. Dissertação, julho (2008).

[16] Vale dos Vinhedos. Available in: http: www.valedosvinhedos. com. br/. Acessed: jan. (2015)

[17] T. Zanini Valduga; J. Rocha Marçal. O Enoturismo no Brasil: um estudo comparativo entre as regiões vinícolas do Vale dos Vinhedos (RS) e do Vale do São Francisco (BA/PE). Turismo em Análise. 21, n. 1, abril (2010)

[18] F. Polita Sostmeyer. O processo de desenvolvimento do Vale dos Vinhedos (Bento Gonçalves - RS). Ijui: UNIJUI, Curso de Pós Graduação Strictu Sensu em Desenvolvimento, Gestão e Cidadania (2006)

[19] C. Guerra Crivellaro et al. Conhecendo o essencial sobre uvas e vinos. EMBRAPA UVA E VINHO: Bento Gonçalves. Documentos $\mathrm{n}^{\mathrm{o}}$ 48. Junho de (2009).

[20] Falcade, F. Mandelli. Vale dos Vinhedos: caracterização geográfica da região. Caxias do Sul, EDUCS (1999)

[21] Valle de Casablanca. Data region. Available in http: / / www. casablancavalley.cl/web/ historia/. Acessed: mar. (2015)

[22] S. Rodríguez Cid; P. Padilla Olivari. Diseño de Plan de Negocios para empresa de servicio que pronostica el correcto término de la fermentación del vino. Valparaiso/Chile: Universidad de Valparaiso, (2014).

[23] J. Costa Silva . Compêndio de Economia Regional ( $2^{a}$ edição), APDR, Coimbra (2005) 